\title{
ISOLATION AND CHARACTERIZATION OF PHOSPHATE SOLUBILIZING DIAZOTROPHIC BACTERIA FROM RHIZOSPHERE OF RICE PLANT OF INDO-NEPAL BORDER
}

\author{
Umesh Prasad Shrivastava \\ Department of Botany, TU, Thakur Ram Multiple Campus, Birgunj, Nepal \\ E-mail: upshrivastava@gmail.com
}

\begin{abstract}
Free-living nitrogen fixing bacteria were isolated from the rhizosphere of rice plant of different regions of Indo-Nepal border. $33.78 \%$ isolates among them showed mineral phosphate solubilization. On the basis of bacterial characterization and identification with Bergey's manual of Determinative Bacteriology (Holt et al, 1994), 38\% isolates showed maximum similarity with Pseudomonas and Azotobacter, 30\% with members of Enterobacteriaceae, 4\% with Gram's positive Microbacterium sp. and $28 \%$ was categorized unknown. ECI $12 \mathrm{~A}$ isolate showed maximum solubilization index (S.I.), o.809 on solid medium whereas $188.65 \mathrm{mg} P / \mathrm{mg}$ dry weight phosphate solubilization in liquid medium. The highest phosphate solubilizing isolate ECI 12A was sequenced after amplification of partial 16S rRNA gene, blast with BLASTn 2.2.17 program of NCBI showed $99 \%$ identity having $99 \%$ query coverage with Microbacterium sp. This isolate has been named as Microbacterium sp. Strain ECI-12A.The sequence of this strain has been deposited in NCBI Gene Bank under accession number EU155122 and this strain has promising potential for developing as a plant growth promoting rhizobacteria (PGPR) as well as biofertilizer.
\end{abstract}

\section{Key words}

Rhizobacteria; PGPR; phosphate solubilization; biofertilizer; phosphate solubilizing bacteria (PSB)

\section{Introduction}

The narrow zone of soil surrounding the root is known as rhizosphere, which is under the immediate influence of the root system. This zone is rich in nutrients in comparison to the bulk soil, due to the accumulation of a variety of organic compounds released from roots by 
exudation, secretion, and deposition (Curl and Truelove, 1986). Because these organic compounds can be used as carbon and energy sources by microorganisms, microbial growth and activity is particularly intense in the rhizosphere. This is reflected by the number of bacteria that are found around the roots of plantsand that isgenerally1o to1oo timeshigher than in the bulk soil (Weller \& Thomashow, 1994). Plant-associated bacteria that are able to colonize roots are called rhizobacteria and can be classified into beneficial, deleterious, and neutral groups on the basis of their effects on plant growth. Beneficial rhizobacteria that stimulate plant growth are usually referred to as Plant- Growth-Promoting Rhizobacteria or PGPR (Davison, 1988; Kloepper et al., 1989). Diazotrophic bacteria, by their ability to convert $\mathrm{N}_{2}$ into ammonia, which can be used by the plant, also belong to the PGPR (Dobbelaere et al. 2003). Because of their competitive advantages in a $\mathrm{C}$-rich, $\mathrm{N}$-poor environment, diazotrophs may selectively enriched in the rhizosphere (Döbereiner and Pedrosa, 1987), putting themselves in a good position to promote plant growth. PGPR, that solubilize the insoluble phosphate present in the soil, are called mineral phosphate solubilizing rhizobacteria. By the activities of mineral phosphate solubilizing rhizobacteria plants are benefited to use the plant available phosphorus. Soil microorganisms are able to solubilize insoluble mineral phosphate by producing various organic acids (Taha et al., 1969; Banik and Dey, 1982; Halder et al., 1990; Illmer et al., 1995; Jones, 1998). This results in acidification of the surrounding soil, releasing soluble orthophosphate ions $\left(\mathrm{H}_{2} \mathrm{PO}_{4}^{-1}\right.$ and $\left.\mathrm{HPO}_{4}^{-2}\right)$ that can be readily taken up by plants. Furthermore, they are able to solubilize organic $\mathrm{P}$ compounds by means of phosphatase enzymes (Greaves and Webley, 1965; Tarafdar and Junk, 1987; Garcia et al., 1992). A large number of P-solubilizing bacteria (PSB) have been isolated from the rhizosphere of several crops. It was estimated that P-solubilizing microorganisms may constitute 20 to $40 \%$ of the culturable population of soil microorganisms and that a significant proportion of them can be isolated from rhizosphere soil (Kucey, 1983; Chabot et al., 1993). Phosphorus is one of the major plant nutrients limiting plant growth. Most agricultural soils contain large reserves of $\mathrm{P}$, a considerable part of which has accumulated as a consequence of regular applications of chemical fertilizers. However, a large proportion of soluble inorganic phosphate added to soil is rapidly fixed as insoluble forms soon after application and becomes unavailable to plants (Rodriguez et al., 1999). Phosphorus fixation and precipitation in soil is generally highly dependent on $\mathrm{pH}$ and soil type. In acid soils, free oxides and hydroxides of $\mathrm{Al}$ and $\mathrm{Fe}$ fix $\mathrm{P}$, while in alkaline soils $\mathrm{Ca}$, causing a low efficiency of soluble $P$ fertilizers, fixes it. The calcium super phosphate fertilizer, which contains about $15 \%$ of phosphorus pentoxide, normally loses its available $\mathrm{P}$ proportion when it comes in contact with soil minerals containing calcium carbonates (Lindsay, 1979). The physical chemical properties of soil of different fields are variable hence it seems that the bacterial populations may vary from place to place.

Since a few phosphate-solubilizing bacteria were reported earlier but most efficient strain is lacking. The mail objective of this present investigation to find out the bacterial population and most efficient diazotrophic phosphate solubilizing rhizobacteria present in the rice fields of India as well as Nepal and to investigate so as to use as biofertilizer.

\section{Materials and methods}

\section{Soil sample collection and isolation of bacteria}

Rice (Oryza sativa L.) plant of Parsa district, Bara district of Nepal and East Champaran district of Bihar and Varanasi district of Uttar Pradesh of India were selected for study. Rhizosphere soil sample were collected carefully by uprooting the root system and placed in a sterile polythene bag 
for transport and stored at $4^{\circ} \mathrm{C}$. 1.0 gram of rhizosphere soil was suspended in $1.0 \mathrm{ml}$. of sterile DDW in sterile test tube and shaken by hands vigorously for proper mixing. After ih of sedimentation process, $1.0 \mathrm{ml}$. of water was taken form the tube and it was mixed in another $9.0 \mathrm{ml}$. of sterile DDW for dilution. 1.0 $\mathrm{ml}$ of bacterial suspension was further diluted in another sterile test tube containing 9.0 ml. DDW. In this way it was diluted $10^{-7}$ dilution. 10o $\mu$ l aqueous phase was kept in solid $\mathrm{JNFb}^{-}$agar plate and spreading was done. It was incubated for 3 days at $37^{\circ} \mathrm{C}$ in BOD incubator and morphologically different colonies appeared on the plates were isolated, sub cultured and enrichment was done in Nfree JNFb- medium (Döbereiner, 1995) devoid of combined nitrogen.

\section{Search and quantification of isolates for their mineral phosphate solubilizing activities}

Search of phosphate solubilizing isolates was done as per the method of Goldstein (1986) as well as Mehta and Nautial (2001) solid medium after the incubation of 3 days at $37^{\circ} \mathrm{C}$ for the detection of phosphate solubilizing isolates. Solubilization index (S.I.) was calculatedusing solid plates of MPVK medium with a few modifications. The MPVK medium comprises $1.0 \%(\mathrm{w} / \mathrm{v})$ glucose, $0.05 \%(\mathrm{w} / \mathrm{v})\left(\mathrm{NH}_{4}\right)_{2} \mathrm{SO}_{4}$ $0.02 \%(\mathrm{w} / \mathrm{v}) \mathrm{NaCl}, 0.02 \%(\mathrm{w} / \mathrm{v}) \mathrm{KCl}, \mathrm{O} .01 \%$ (w/v) $\mathrm{CaCl}_{2}-2 \mathrm{H}_{2} \mathrm{O}$, o.01\% (w/v) $\mathrm{MgSO}_{4}-7 \mathrm{H}_{2} \mathrm{O}$, $0.05 \%(\mathrm{w} / \mathrm{v}) \quad \mathrm{MnSO}_{4}-7 \mathrm{H}_{2} \mathrm{O}, \quad 0.05 \% \quad(\mathrm{w} / \mathrm{v})$ $\mathrm{FeSO}_{4}-7 \mathrm{H}_{2} \mathrm{O}, 0.05 \%(\mathrm{w} / \mathrm{v})$ yeast extract and $0.5 \%(\mathrm{w} / \mathrm{v}) \mathrm{Ca}_{3}\left(\mathrm{PO}_{4}\right)_{2}$ in distilled water $(\mathrm{pH}$ 7.5). $\mathrm{Ca}_{3}\left(\mathrm{PO}_{4}\right)_{2}^{3}$ was autoclaved first. Then, the other sterile ingredients were aseptically mixed after autoclaving. 1.0 $\mathrm{ml}$ bromophenol blue was added from $0.4 \%(\mathrm{w} / \mathrm{v})$ stock solution of the dye prepared in ethanol $(\mathrm{pH}$ 6.7 adjusted with o.1N NaOH) in $100 \mathrm{ml} \mathrm{MPVK}$ medium. For S.I. study, $1.0 \mathrm{ml}$ of overnight NB grown bacterial culture was taken; it was washed with normal saline $(0.85 \% \mathrm{w} / \mathrm{v} \mathrm{NaCl})$ after adjusting equal O.D. (o.3) for all isolates. Now, it was resuspended in $1.0 \mathrm{ml}$ normal saline. $10 \mu \mathrm{l}$ suspended bacterial isolates were inoculated on solid MPVK medium in triplicate for estimation of S.I. of phosphate solubilization. Colony diameter (CD) and colony diameter + halozone (TCD) were recorded after 3 days incubation at $37^{\circ} \mathrm{C}$. The S.I. was calculated using formula (S.I. $=(\mathrm{TCD}$ - CD)/ TCD). The quantification of phosphate solubilization was done in liquid Nautial medium after 3 days of incubation at $37^{\circ} \mathrm{C}$. Calcium tri phosphate was used as standard for quantification by spectrophotometer. Estimation of free phosphate released in the medium as a result of phosphate solubilization by the bacterial isolates was estimated as per the method of Marinetti (1962). Reagent A: $10 \%$ Ascorbic acid (stored at $4^{\circ} \mathrm{C}$ ) Reagent B: o. $42 \%$ Ammonium molybdate in $1 \mathrm{~N} \mathrm{H}_{2} \mathrm{SO}_{4}$ (stored at room temperature) Reagent $\mathrm{C}: 1$ part of reagent A + 6 part of reagent B. $1.5 \mathrm{ml}$ of 3 days old grown cultures was harvested by centrifugation at $8000 \mathrm{rpm}$ for $2 \mathrm{~min} .3 \cdot 5$ $\mathrm{ml}$ of reagent $\mathrm{C}$ was added to the culture supernatant of each bacterial sample and after mixing, incubated at room temperature for 1 h. Optical density was measured at 660 nm against blank. Simultaneously, standard with various concentrations of $\mathrm{K}_{2} \mathrm{HPO}_{4}$ was prepared separately.

\section{6 rRNA gene amplification and sequencing}

Amplification of 16S rRNA gene of the best phosphate solubilizing isolate ECI 12-A was performed. The PCR reaction mixture contains 36.0 $\mu \mathrm{l} \mathrm{H}_{2} \mathrm{O}$, 5.0 $\mu \mathrm{l}$ of $10 \mathrm{X}$ buffer, 0.125 $\mu \mathrm{l}$ each primer (Forward: 5'- ACT GGC GGA CGG GTC AGT AA- 3'and Reverse: 5'- CGT ATT ACC GCG GCT GCT GG-3'), $0.5 \mu$ l of each dNTPs (10 mM), $0.5 \mu$ l of 3.0 U Taq polymerase and $4.0 \mu \mathrm{l}$ template DNA. Amplification was performed with thermal profile having initial denaturaton at $95^{\circ} \mathrm{C}$ for 3 minute, 30 cycles of denaturation at $94^{\circ} \mathrm{C}$ for 1 minute, annealing at $50^{\circ} \mathrm{C}$ for 1 minute and extention at $72^{\circ} \mathrm{C}$ for 1 minute 10 second with final extention at $72^{\circ} \mathrm{C}$ for 5 minutes.

The amplified $16 S$ rRNA gene was sequenced 
with ABI PRISM model 3730 version 3.0 DNA sequencer.

\section{Sequence analysis and multiple alignments with known P-solubilizing bacteria}

The generated $16 S$ rRNA gene sequence of isolate ECI 12-A was analyzed by blast with BLASTn program of NCBI online on website: http://www.ncbi.nlm.nih.gov/BLAST/. $\quad 16 S$ rRNA gene sequences of few well known p-solubilizing bacteria were taken from NCBI Gene Bank and aligned with our generated sequence of Microbacterium sp. strain ECI 12-A with ClustalW program online on website: http://align.genome.jp/.

\section{Nucleotide sequence accession number}

Sequence obtained in this study has been submitted in NCBI Gene Bank which can be viewed under accession number EU155121. 16S $r R N A$ genes of known phosphate solubilizing strains were taken from data of Gene Bank for alignments with gene sequence of this study.

\section{Statistical analysis}

Statistical calculation of the S.I was calculated for the t-test and significance study using online tool with the website http://home. calara.net/sisa/t-test.html. The confidence interval was taken $95 \%$ the $\mathrm{P}$ value $(<0.05)$ was the level of significance.

\section{Results}

\section{Mineral Phosphate solubilization Characterization}

All the phosphate-solubilizing isolates were analyzed by measuring the $\mathrm{CD}$ and TCD of the isolates for the determination of S.I. on the MRVK agar plate containing bromophenol $\mathrm{pH}$ indicator. The yellow or orange halozones were formed around phosphate solubilizing bacteria (Fig. 1). There were three categories of bacteria were found depending on the formation of halozone. First category of isolates did not grow, the second, grew on the plate but did not produce halozone and the third, produced yellow or orange halozones (Fig. 1) due to acid production presence of bromophenol $\mathrm{pH}$ indicator in the medium. The change in colour was found due to acidification of the medium by the p-solubilization. It was found that's.I. ranges from 0.118 to 0.809 as shown in Table1. The highest S.I. was recorded in isolate ECI $12 \mathrm{~A}$. For the confirmation and most accurate determination, quantification was also done. According to quantification data ECI 12A again showed maximum phosphate solubilizing potential $(188.65 \mu \mathrm{g} \mathrm{P} / \mathrm{mg}$ dry weight). The phosphate solubilizing potential of ECI $12 \mathrm{~A}$ was found promising sufficient to be an efficient PGPR. The $\mathrm{pH}$ of the medium was measured at the time of quantification of P; it was found 3.0 to 5.4 (data not shown) due to production of acids in the medium.

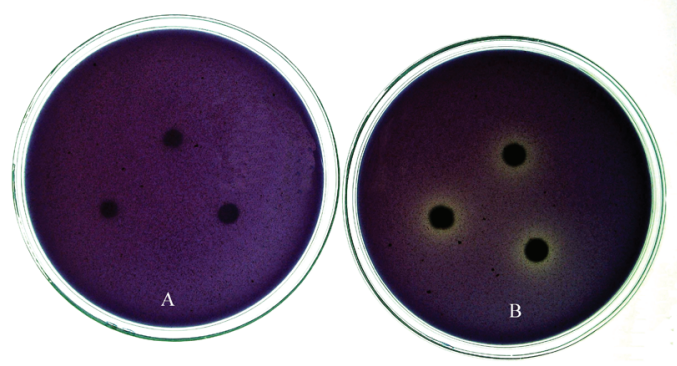

Fig. 1: Phosphate solubilization plate assay showing halozones of phosphate solubilization. A. No solubilization, B. Halozones of solubilization. Inoculation was done in triplicate of same isolate in a plate.

Statistical calculation for t-test was done online with ewbsite http:// home.clara.net/ sisa/t-test.html CD = Colony diameter, TCD = Colony diameter + halozone diameter, S.I = solubilization index. All records are mean of three independent readings. 
Table 1: Phosphate solubilization records showing CD, TCD, S.I. P-value and quantification of phosphate solubilizing isolates

\begin{tabular}{|c|c|c|c|c|c|c|}
\hline \multirow[t]{3}{*}{ S.N. } & \multirow[t]{3}{*}{ Isolates } & \multicolumn{5}{|c|}{ Phosphate solubilization } \\
\hline & & CD (mm.) & TCD (mm.) & S.I. & P Value & $\mu g$ P mg $^{-1}$ dry weight \\
\hline & & Mean \pm S.D. & Mean \pm S.D & & & \\
\hline 1 & $\mathrm{ECI} 2 \mathrm{~A}$ & $4.67 \pm 0.577$ & $11 \pm 1$ & 0.575 & 0.0027 & 92.13 \\
\hline 2 & $\mathrm{ECI} 2 \mathrm{~B}$ & $4.67 \pm 0.577$ & $7 \pm 1$ & 0.333 & 0.0099 & 16.04 \\
\hline 3 & $\mathrm{ECI}{ }_{5} \mathrm{~B}$ & $6.33 \pm 0.577$ & $18.67 \pm 1.155$ & 0.661 & 0.0005 & 140.06 \\
\hline 4 & $\mathrm{ECI} 7 \mathrm{~A}$ & $4.67 \pm 0.577$ & $25.67 \pm 0.577$ & 0.818 & o & 52.88 \\
\hline 5 & $\mathrm{ECI} 7 \mathrm{D}$ & $4.33 \pm 0.577$ & $6.67 \pm 0.577$ & 0.351 & 0.0077 & 16.04 \\
\hline 6 & ECI 9A & $5.33 \pm 0.577$ & $7.667 \pm 0.577$ & 0.305 & 0.0077 & 12.9 \\
\hline 7 & ECI 9B & $5.33 \pm 0.577$ & $9.333 \pm 0.577$ & 0.429 & 0.0011 & 40.37 \\
\hline 8 & ECI 10A & $4.33 \pm 0.577$ & $6.333 \pm 0.577$ & 0.316 & 0.0132 & 13.25 \\
\hline 9 & $\mathrm{ECI} 11 \mathrm{C}$ & $5.67 \pm 0.577$ & $9.333 \pm 1.155$ & 0.392 & 0.0015 & 40 \\
\hline 10 & $\mathrm{ECI} 12 \mathrm{~A}$ & $4.33 \pm 0.577$ & $22.67 \pm 1.155$ & 0.809 & 0.0001 & 188.65 \\
\hline 11 & $\mathrm{AF}{ }_{1} \mathrm{C}$ & $4.67 \pm 0.577$ & $5.067 \pm 0.577$ & 0.176 & 0.101 & 12.47 \\
\hline 12 & $A F_{1} \mathrm{D}$ & $5.33 \pm 0.577$ & $6.667 \pm 1.155$ & 0.201 & 0.1677 & 12.74 \\
\hline 13 & $\mathrm{AF}_{4} \mathrm{~B}$ & $5 \pm 1$ & $7 \pm 1$ & 0.286 & 0.0705 & 18.05 \\
\hline 14 & $\mathrm{AF}_{4} \mathrm{C}$ & $5.67 \pm 0.577$ & $7 \pm 0$ & 0.19 & o & 14.08 \\
\hline 15 & $\mathrm{AF}{ }_{5} \mathrm{~A}$ & $5.67 \pm 0.577$ & $7.333 \pm 0.577$ & 0.227 & 0.0242 & $17 \cdot 47$ \\
\hline 16 & $\mathrm{AF}_{5} \mathrm{D}$ & $4.33 \pm 0.577$ & $7.33 \pm 0.577$ & 0.41 & 0.0031 & 34.45 \\
\hline 17 & $\mathrm{PN}_{4} \mathrm{D}$ & $5.33 \pm 0.577$ & $7.667 \pm 0.577$ & 0.305 & 0.0077 & $17 \cdot 47$ \\
\hline 18 & $\mathrm{PN}_{7} \mathrm{C}$ & $5.67 \pm 0.577$ & $6.667 \pm 0.577$ & 0.15 & 0.1018 & 12.47 \\
\hline 19 & $\mathrm{BN} 1 \mathrm{~A}$ & $5.33 \pm 0.577$ & $7.667 \pm 1.155$ & 0.305 & 0.0506 & 15.66 \\
\hline 20 & $\mathrm{BN}_{1} \mathrm{C}$ & $5 \pm 0$ & $6.333 \pm 0.577$ & 0.21 & 0.775 & 14.27 \\
\hline 21 & $\mathrm{BN} 2 \mathrm{~A}$ & $4.33 \pm 0.577$ & $6.667 \pm 1.155$ & 0.351 & 0.0506 & 20.78 \\
\hline 22 & $\mathrm{BN}_{4} \mathrm{~A}$ & $5 \cdot 33 \pm 1.155$ & $8.667 \pm 0.577$ & 0.385 & 0.0202 & 33.17 \\
\hline 23 & $\mathrm{BN}_{5} \mathrm{C}$ & $5.33 \pm 0.577$ & $7.333 \pm 0.577$ & 0.273 & 0.0131 & 12.23 \\
\hline 24 & $\mathrm{BN}_{7} \mathrm{C}$ & $7.33 \pm 0.577$ & $8.667 \pm 1.155$ & 0.154 & 0.1677 & 12.17 \\
\hline 25 & $\mathrm{BN}_{9} \mathrm{C}$ & $5 \pm 1$ & $5.667 \pm 0.577$ & 0.118 & 0.404 & 11.52 \\
\hline
\end{tabular}

16 rRNA gene amplification and sequence analysis

The sequence of $16 S$ rRNA gene of ECI 12-A showed $99 \%$ maximum identity with $99 \%$ query coverage with most of the Microbacterium sp and Microbacteriaceae bacterium such as Microbacterium sp 022s1-13 (accession no- AB266330), Microbacteriaceae bacterium KVD-unk-67 (accession noDQ490447.1), Microbacterium laevaniformans LA (accession no- AF535159). (See Fig 2)

\section{Discussion}

Plant growth promotion has been reported by the solubilization of insoluble $\mathrm{P}$ in the soluble form by the activities of PGPR (Rodríguez and Fraga, 1999; Richardson, 2001). It is well known that $\mathrm{P}$ is an essential nutritional element for plant. But, it is one of the least soluble nutrient ions in the environment; therefore, less than $5 \%$ of total soil phosphate is available to plants (Epstein, 1972; Brown, 1974). Phosphorus exists in nature in a variety of organic (derived from microorganisms and plants) and inorganic (originating from 


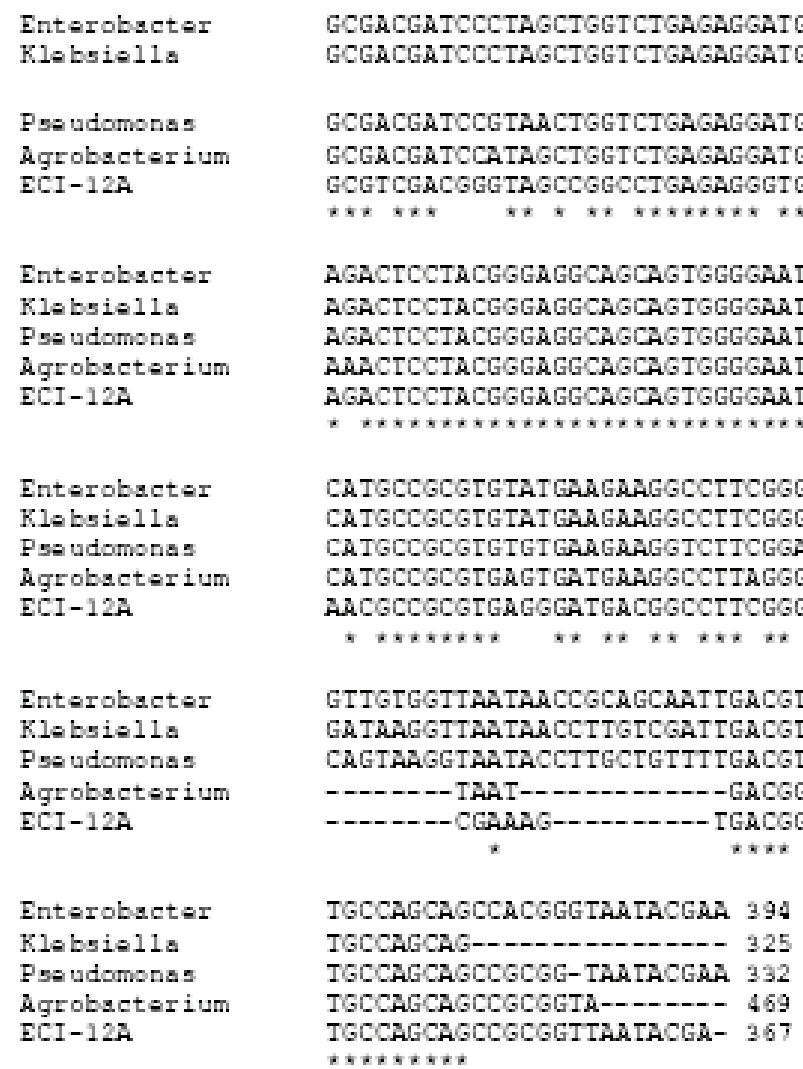

IGCCAGCAGCCACGGGTAATACGAA 394

IGCCAGCAG--.-.-.-- 325

IGCCAGCAGCCGCGG-TAATACGAA 332

IGCCAGCAGCCGCGGTA--.-.-- 469

IGCCAGCAGCCGCGGTTAATACGA- 367

$* * * * * * * *$

GCGACGATCCCTAGCTGGTCIGAGAGGATGACCAGCCACACTGGAACIGAGACACGGICC 199 GCGACGATCCCTAGCTGGTCTGAGAGGATGACCAGCCACACTGGAACTGAGACACGGTCC 136

GCGACGATCCGTAACTGGICIGAGAGGATGATCAGICACACTGGAACTGAGACACGGTCC 129 GCGACGATCCATAGCTGGTCTGAGAGGATGATCAGCCACATTGGGACTGAGACACGGCCC 297 GCGTCGACGGGTAGCCGGCCIGAGAGGGTGACCGGCCACACTGGGACTGAGACACGGCCC 193

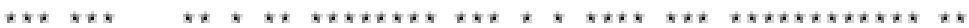

AGACTCCIACGGGAGGCAGCAGIGGGGAATATTGCACAATGGGCGCAAGCCTGATGCAGC 249 AGACTCCIACGGGAGGCAGCAGTGGGGAATATTGCACAATGGGCGCAAGCCTGATGCAGC 196 AGACTCCTACGGGAGGCAGCAGTGGGGAATATTGGACAATGGGCGARAGTCT-ATOCAGC $18 \mathrm{E}$ ARACICCTACGGGAGGCAGCAGTGGGGAATATTGGACAATGGGCGCAAGCCTGATCCAGC 357 AGACTCCTACGGGAGGCAGCAGTGGGGAATATTGCACAATGGGCGARAGCCTGATGCAGC 243 $* * * * * * * * * * * * * * * * * * * * * * * * * * * * * * * * * * * * * * * * * * * * * * * * *$

CATGCCGCGIGTATGAAGAAGGCCTTCGGGTTGTAAAGTACTITCAGCGGGGAGGAAGGI 309 CATGCCGCGIGTATGAAGAAGGCCITCGGGTTGTAAAGTACTTICAGCGGGGAGGAAGGC 256 CATGCCGCGIGTGTGAAGAAGGTCTICGGATTGTAAAGCACTTIAAGITGGGAGGAAGGG 248 CATGCCGCGIGAGTGATGAAGGCCTTAGGGTTGTAAAGCICTTICACCGGAGAAGA---- 413 AACGCCGCGIGAGGGATGACGGCCITCGGGTTGTAARCCTCTITTAGCAGGGAAGAAG-- 301

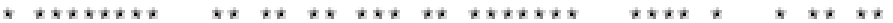

GTTGIGGTTAATAACCGCAGCAATTGACGTTACCCGCAGAAGAAGCACCGGCTAACTCCG 369 GATAAGGTIAATAACCTTGICGATTGACGTIACCCGCAGAAGAAGCACCGGCTAACTCCG 316 CAGTAAGGTAATACCITGCIGTITTGACGITACCAACAGAATAAGCACCGGCTAACTTCG 309

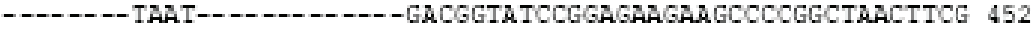

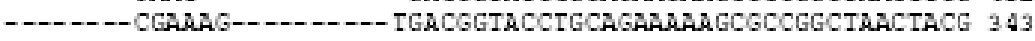

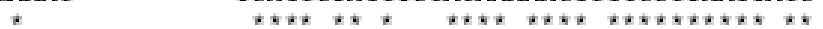

-

-

IGGAGAGITIGATCCIGGCTCAGAACGAACGCIGGCGGCAGGCTTAACACATGCAAGTCG 60

-

GGGATACTACTGGARACGG 19

-

AACGCCCCGCARGGGGAGTGGCAGACGGGIGAGTAACGCGTGGGAATCTACCGTGCCCTG 120 -

TAGCTAATACCGCATAACGICGCAAGACCAAAGAGGGGGACCT--TCGGG--1----CC 69 工 CGGAATAGCTCCGGGARACTGGAATTAATACCGCATACGCCCT--ACGGGGG-AAAGATT 177 IGGAACGGCGTCTAATACTGGATACGAACCGTGGAGGCATCTTCAACGGITGGAAAGATI 63 $* * *$

ICTIGCCATCAGATGIGCCCAGATGGGATTAGCTAGTAGGTGGGGTAACGGCTCACCTAG 129 ICTIGCCATCACATGIGCCCAGATGGGATIAGCTAGGAGGTGGGGTAACGGCTCACCTAC 76 TCACGCTATCAGATGAGCCTAGGTCGGATTAGCTAGTIGGIGGGGTAAAGGCCTACCAAG 69 IATCGGGGTATGATGAGCCCGCGTIGGATIAGCTAGTIGGIGGGGTAAAGGCCTACCAAG 237 IIITGGTCAGGGATGAGCTCGCGGCCTATCAGCTIGTIGGIGAGGTAATGGCTCACCAAG 123

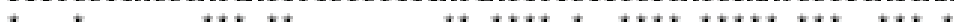

Fig 2: Partial 16S rRNA gene sequence of best phosphate solubilizing isolate ECI 12A alignment with four other four p-solubilizing strains from gene bank. 
applied P fertilizer) forms that are insoluble to very poorly soluble (Paul and Clark, 1989). Therefore, theaddition of phosphate fertilizers has become a common practice in modern agriculture. However, a large portion of the soluble inorganic phosphate applied to soil as fertilizer is rapidly immobilized by the iron and aluminium in acid soils and by calcium in calcareous soils soon after application, thus becoming unavailable to plants (Chang and Chu, 1961; Lindsay, 1979; Sanyal and De Datta, 1991; Holford, 1997). Soil microorganisms are able to solubilize insoluble mineral phosphate by producing various organic acids (Taha et al., 1969; Banik and Dey, 1982; Halder et al., 1990; Illmer et al., 1995; Jones, 1998). This results in acidification of the surrounding soil, releasing soluble orthophosphate ions $\left(\mathrm{H}_{2} \mathrm{PO}_{4}\right.$ ${ }^{-1}$ and $\mathrm{HPO}_{4}^{-2}$ ) that can be readily taken up by plants. In our investigation $33.78 \%$ phosphate solubilizing isolates were found among the total diazotrophic isolates, which shows agreement with the estimation of Kucey, 1983 and Chabot et al., 1983. According to them 20 to $40 \%$ of the culturable bacterial population of soil solubilize P. Although there is good evidence for P-solubilization by these microorganisms in pure culture (Taha et al., 1969; Bajpai and Sundara Rao, 1972; Banik and Dey, 1981; Chabot et al., 1993), it is not easy to demonstrate $\mathrm{P}$ solubilization in plant-microorganism systems. Experiments performed with P-solubilizing diazotrophs are few, and the results obtained quite diverse, varying according to plant or bacterial species. Bacillus megaterium and P. polymyxa are able to enhance growth and yield but not the P uptake of canola, indicating that P-solubilization

is not the main mechanism responsible for positive growth response (de Freitas et al., 1997). Kumar and Narula (1999) used chemically induced mutants of Azotobacter chroococcum, isolated from the wheat rhizosphere, with higher phosphatesolubilization activity to inoculate wheat and found significantly positive effects of inoculation on percent germination and growth emergence, with the mutant strains performing better than the parent strain. We are now investigating the response of the highest p-solubilizing isolate on rice plant and uptake of $\mathrm{P}$ in this plant.

\section{Acknowledgements}

Financial supports as SAARC scholarship under Indo-Nepal bilateral cooperation scheme of ICCR, Government of India is gratefully acknowledged. The author is grateful to Tribhuvan University, Nepal for providing study leave for this study and Prof. Ashok Kumar, School of Biotechnology, Banaras Hindu University for his guidance and laboratory facility.

\section{References}

Bajpai, P.D. \& Sundara Rao, W.V.B. (1972). Phosphate solubilizing bacteria. Part I. Solubilization of phosphate in liquid culture by selected bacteria as affected by different $\mathrm{pH}$ values. Soil Sci.Plant Nutr. 17: 41-53.

Banik, S. \& Dey, B. K. (1981). Phosphate solubilizing microorganisms of a lateritic soil. I. Solubilization of inorganic phosphates and production of organic acids by microorganisms, isolated in sucrose calcium phosphate agar plates. Zbl. Bakt II: 478-486.

Banik, S. \& Dey, B. K. (1982). Available phosphate content of an alluvial soil is influenced by inoculation of some isolated phosphatesolubilizing microorganisms. Plant Soil 69: 353-364.

Brown, M. E. (1994). Seeds and root bacterization. Annu. Rev. Phytopathol. 12: 181-197.

Chabot, R., Antoun, H. \& Cescas, M. P. (1993). Stimulation de la croissance du maïs et de la laitue romaine par des microorganismes dissolvant le phosphore inorganique Can. J. Microbiol. 39: 941-947

Chang, S.C. \& Chu, W. K. (1961). The fate of soluble phsosphate applied to soils. J. Soil Sci. 12: 286293. 
Curl, E.A. \& Truelove, B. (1986). The Rhizosphere, Springer- Verlag, Berlin.

Davison, J. 1988. Plant beneficial bacteria. Bio/ Technology 6: 282-286.

de Freitas, J. R., Banerjee, M.R. \& Germida, J. J. (1997). Phosphate-solubilizing rhizobacteria enhance the growth and yield but not phosphorus uptake of canola (Brassica napus L.). Biol. Fertil. Soils 24: 358-364.

Dobbelaere, S., vanderleyden, J. \& Okon, Y. (2003). Plant growth-promoting effects of diazotrophs in the rhizosphere. Critical review in Plant Sciences. 22: 107-149.

Döbereiner, J. (1995). Isolation and identification of aerobic nitrogen-fixing bacteria from soil and plants. In K. Alef \& P. Nannipieri (Eds.). Methods in applied soil microbiology and biochemistry. London: Academic Press, pp 134141.

Döbereiner, J. \& Pedrosa, F.O. (1987). NitrogenFixing Bacteria in Nonleguminous Crop Plants. Madison: Science Tech, Inc.

Epstein, E. (1972). Mineral Nutrition of Plants. New York: John Wiley \& Sons, Inc.

Garcia, C., Fernandez, T., Costa, F., Cerranti, B., \& Masciandaro, G. (1992). Kinetics of phosphatase activity in organic wastes. Soil. Biol. Biochem. 25: $361-365$.

Goldstein, A.H. (1986). Bacterial solubilization of mineral phosphates: historical perspective and future prospects. Am. J. Alter. Agric. 1:51-57.

Greaves, M.P. \& Webley, D.M. (1965). A study of the breakdown of organic phosphates by microorganisms from the root region of certain pasture grasses. J. Appl. Bact. 28: 454-465.

Halder, A. K., Mishra, A. K., Bhattacharyya, P. \& Chakrabartty, P. K. (1990). Solubilization of rock phosphate by Rhizobium and Bradyrhizobium.
J. Gen. Appl. Microbiol. 36: 81-92.

Holford, I.C.R. 1997. Soil phophorus, its measurements and its uptake by plants. Austr. J. Soil Res. 35: 227-239.

Holt, J.G., N.R. Sneath, P.H.A., staley, J.T. \& Williams, S.T. (1994). Bergey's Mannual of Determinative Bacteriology. Baltimore: Williams and Wilkins,.

Illmer, P., Barbato, A., \& Schinner, F. (1995). Solubilization of hardly soluble $\mathrm{AlPO}_{4}$ with P-solubilizing microorganisms. Soil Biol. Biochem. 27: 265-270.

Jones, D.L. (1998). Organic acids in the rhizosphere — a critical review. Plant Soil 205: 25-44.

Kloepper, J.W., Lifshitz, R., \& Zablotowicz, R.M. (1989). Free-living bacterial inocula for enhancing crop productivity. Trends Biotechnol. 7:39-43.

Kucey, R.M.N. (1983). Phosphate-solubilizing bacteria and fungi in various cultivated and virgin Alberta soils. Can. J. Soil Sci. 63: 671-678.

Kumar, V. \& Narula, N. (1999). Solubilization of inorganic phosphates and growth emergence of wheat as affected by Azotobacter chroococcum mutants. Biol. Fertil. Soils 28: 301-305.

Lindsay, W.L. (1979). Chemical Equilibria in Soils. New York: John Wiley \& Sons.

Marineitti, G.V. (1962). Chromatographic separation, identification and analysis of phosphatides. J.Lipid Res. 3: 1-20.

Mehta, S. \& Nautial, C.S. (2001). An efficient method for qualitative screening of phosphate -solubilizing bacteria. Curr. Microbiol. 43: 5156.

Paul, E.A. \& Clark, F.E. (1989). Soil Microbiology and Biochemistry. San Diego: Academic Press.

Richardson, A.E. (2001). Prospects for using soil 
microorganisms to improve the acquisition of phosphorus by plants. Aust. J. Plant Physiol. 28: 897-906.

Rodríguez, H. \& Fraga, R. (1999). Phosphate solubilizing bacteria and their role in plant growth promotion. Biotechnol. Adv. 17: 319-339.

Sanyal, S.K. \& De Datta, S.K. (1991). Chemistry of phosphorus transformations in soil. Adv. Soil Sci. 16: 1- 120.

Taha, S.M., Mahmoud, S.A.Z., Halim El-Damaty, A. \& Abd El-Hafez, A.M. 1969. Activity of phosphatedissolving bacteria in Egyptian soils. Plant Soil 31: 149-16o.
Tarafdar, J.C. \& Junk, A. (1987). Phosphatase activity in the rhizosphere and its relation to the depletion of soil organic phosphorus. Biol. Fertil. Soil 3: 199-204.

Weller, D. M. \& Thomashow, L. S. (1994). Current challenges in introducing beneficial microorganisms into the rhizosphere. In F. O'Gara, D. N. Dowling \& B. Boesten, (Eds.), Molecular Ecology of Rhizosphere Microorganisms. Biotechnology and the Release of GMOs, pp. 1-18, VCH Verlagsgesellschaft $\mathrm{mbH}$, Weinheim, Germany. 